\title{
THE EFFECTIVENESS OF PROBLEM POSING TYPE OF POST SOLUTION POSING AND COOPERATIVE TYPE OF THINK PAIR SQUARE (TPSQ) LEARNING MODEL FOR STUDENT AT SEVENTH GRADE OF SMP MUHAMMADIYAH 1 SLEMAN IN EVEN SEMESTER OF ACADEMIC YEAR 2015/2016
}

\author{
Mega Yanalisa Pradina ${ }^{a}$, Widayati ${ }^{b}$ \\ Mathematics Education Study Program, Universitas Ahmad Dahlan \\ Jalan Ring Road Selatan, Tamanan, Banguntapan, Bantul Yogyakarta \\ amypinkrose414@gmail.com, bummunabilah67@gmail.com
}

\begin{abstract}
This research is done because of the application of usual teaching system that is dominated by teacher and the learning teaching process is not enjoyable, so that it needs the teaching method involving the students in order the students will be more active and consider learning is enjoyable. This research is purposed to know the effectiveness of Problem Posing type Post Solution Posing and cooperative type of Think Pair Square (TPSQ) learning model for students at seventh grade in SMP Muhammadiyah 1 Sleman in even semester of academic year 2015/2016. The kind of this research is experimental research. The population in this research is the students at seventh grade in SMP Muhammadiyah 1 Sleman of academic year 2015/2016, which is divided into three classes in total ninety six students. Sample taking used random sampling technique so it can be got in class VII C as the experimental class I (Post Solution Posing) and class VII A as the experimental class II (Think Pair Square (TPSQ)). The collecting data is done using documentation and test methods. The analysis data technique used is to pre-requirement analysis test including normality test using Chi-Square formula, homogeneity test using Barlett test formula, and Hypotheses test using $t$-test. The research's result in significant level of $5 \%$ and $\mathrm{db}=62$ shows that: (1) there is a difference between the result in learning mathematics in students learning mathematics using Problem Posing type of Post Solution Posing learning model to the students using cooperative type of TPSQ. It is shown in the result of first hypotheses test, it results value $t_{\text {count }}=2,581>t_{\text {table }}=1,99962$. (2) Problem Posing type of Post Solution Posing is more effective compared by cooperative type of TPSQ. This is seen using the result of second hypotheses test, it results value $t_{\text {count }}=2,581>t_{\text {table }}=1,67017$.
\end{abstract}

Keyword: Effectiveness, Learning Outcomes, Post Solution Posing, Think Pair Square (TPSQ).

\section{INTRODUCTION}

At present the world of education is being faced with various changes in various aspects of life in society. These changes are caused by the development of science and technology. In these changes, the world of education is required to be able to make a real contribution, namely improving the quality of results and education services to the community. Along with the development of increasingly rapid technology, the world of education needs to hold innovations and updates, especially in its implementation strategy. Therefore, education is an interesting problem to continue to develop for the better.

Mathematics is one of the subjects taught at every level of education from elementary school to high school, even in higher education in certain majors mathematics is still taught. This is done because mathematics is a science that is used as an introduction to other sciences. Therefore, mathematics is needed by everyone in everyday life.

The learning process, especially mathematics learning, teachers should prefer a variety of approaches, strategies, methods that are appropriate to the situation so that the learning objectives are achieved. Whether or not a selection of learning models will depend on the purpose of learning, compatibility with learning material, the level of development of students (students), the ability of teachers to manage learning and optimize existing resources.

One learning model that optimizes students in learning is Problem Posing learning and cooperative learning. Some variations in the Problem Posing learning model one of them is the Post Solution Posing model. Problem Posing Learning Type Post Solution Posing trains students to make 
similar questions like those made by the teacher. Some variations in the cooperative learning model one of them is the Think Pair Square (TPSQ) model. TPSQ type cooperative learning trains students to work alone and cooperate with others so as to encourage students to be active in learning.

Based on observations on October 6, 2015 to determine the situation and conditions of learning carried out by class VII teachers of SMP Muhammadiyah 1 Sleman. The results of the observations show that the learning done by the teacher uses the conventional method (the lecture method accompanied by question and answer, problem training, and assignment of tasks) is more dominant in learning activities in the classroom. As long as learning activities take place, students are less active in participating in learning, lack of cooperation with friends, and less enthusiastic so learning that should involve students to actively ask questions and discuss material is not visible. Students also sometimes feel unsure about the results of their own work so there are still few students who are confident to present the results of their work in front of the class. The lack of teacher strategies in managing the learning activities resulted in the learning process being ineffective and there were still many low mathematics scores.

Based on the results of the Final exam in academic year of 2015/2016 on mathematics subjects, it was shown that the average mathematics scores of seventh grade students of SMP Muhammadiyah 1 Sleman were still below the Minimum Completion Criteria (MCC) which were expected and set at 70 . Even, no students get the value of the Final Semester Examination above the CCM. This shows that the mathematics learning outcome are still low. The low learning outcomes of students, must be corrected immediately so that it matches the expected goals.

The unsuccessful learning outcomes of mathematics can be caused by several factors such as teacher-centered learning so that students' activeness in solving mathematical problems is still lacking, the learning model used is less varied so students become bored quickly, mathematics is still considered difficult by students, causing students to be reluctant to learn mathematics, consequently has an impact on the low learning outcomes of mathematics. Thus there must be a solution made by the teacher so that the mathematics learning outcomes are more maximal. But to realize maximum learning outcomes requires the collaboration of all school members to play an active role in improving the quality of education in schools.

The objectives to be achieved from the implementation of this research are:

1. To find out whether or not there is a difference between the mathematics learning outcomes of students learning using the Problem Posing learning model type Post Solution Posing and the mathematics learning outcomes of students using the Think Pair Square (TPSQ) cooperative learning model on VII grade students in the even semester of SMP Muhammadiyah 1 Sleman of academic eyar 2015/2016.

2. To find out the effectiveness of the Problem Posing learning model type Post Solution Posing with the cooperative learning model Think Pair Square (TPSQ) on the mathematics learning outcomes of class VII students in the even semester of SMP Muhammadiyah 1 Slemanof academic year 2015/2016.

\section{METHODS}

The type of research conducted by researchers is to use experimental research methods. The experimental research method is a research method used to look for the effect of certain treatments. Based on the type of research, experimental research methods are included in quantitative methods. Quantitative research methods can be interpreted as research methods based on the philosophy of positivism, used to examine certain populations or samples, sampling techniques are generally carried out randomly, data collection uses research instruments, data analysis is quantitative / statistical in order to test hypotheses that has been established. This research was conducted at SMP Muhammadiyah 1 Sleman. Data retrieval is carried out on class VII students even semester of academic year 2015/2016. The population in this study were seventh grade students of SMP Muhammadiyah 1 Sleman in even semester of academic year 2015/2016. Which consists of 3 classes namely VII A, VII B, and VII C with the number of students 96. Sampling is done by random sampling technique for the class, which is taking sample classes by lottery 
to determine experiment class 1 and experiment class 2 . The class chosen as the sample class is class VII $\mathrm{C}$ and class VII A, where class VII C is class Experiment 1 was treated using the Problem Solution Posing Posing learning model and VII A class as the experimental class 2 which was treated using the TPSQ type cooperative learning model.

Research design is all the processes needed in planning and implementation. In this study the research design used was a form of experimental design in the form of True Experimental Design with the type of Posttest-Only Control Design. This research is an experimental research involving experimental class 1 and experimental class 2. In experimental class I learning was done using the Problem Posing learning model type Post Solution Posing and in the experimental class II using the TPSQ type cooperative learning model. In this design, there are two classes, each chosen randomly (R). The data collection technique in this study was to use a test of mathematics learning outcomes and documentation of preliminary ability data (Values of Odd Semester 2015/2016 Academic Year). In this study the instruments used were test questions that were used to find out the results of learning mathematics. The test questions for mathematics learning outcomes used are in the form of multiple choices with four alternative answers, namely a, b, c, and d with the right answers given a score of 1 and the wrong answers given a score of 0.Test of prerequisite for analysis using normality test and homogeneity test. Test the Hypothesis using two-tail and one-tail hypothesis.

\section{RESULTS AND DISCUSSION}

\section{Description of Initial Capability Value}

Table 1. Summary of Description of Initial Capability (UAS Value)

\begin{tabular}{|l|c|c|}
\hline \multicolumn{1}{|c|}{ Variable } & Class Experiment I & Class Experiment II \\
\hline $\begin{array}{l}\text { The number of } \\
\text { students }\end{array}$ & 32 & 32 \\
\hline The highest score & 50 & 55 \\
\hline Lowest value & 15 & 10 \\
\hline Average $(\bar{x})$ & 31,17 & 28,67 \\
\hline $\begin{array}{l}\text { Standard } \\
\text { Deviation }(S)\end{array}$ & 9,43962938 & 10,62529649 \\
\hline Variance $\left(S^{2}\right)$ & 89,10660282 & 133,8646673 \\
\hline
\end{tabular}

\section{Preliminary Ability Value Normality Test Results}

In the experimental class I $\chi^{2}$ count $=2,1187<\chi_{\text {table }}^{2}=9,4877$ with a significance level of $5 \%$ and degrees of freedom 2 , so that the value of the ability of the initial experimental class is normally distributed data. Whereas in class experiment II $\chi_{\text {count }}^{2}=1,2422<\chi_{\text {table }}{ }^{2}=$ 7,8147 with a significance level of $5 \%$ and the degree of freedom 2 . So that the value of the ability of the initial experimental class is normally distributed data.

\section{Initial Capability Homogeneity Test Results}

Based on the homogeneity test that has been carried out in experimental class I and class II, it was obtained $\chi_{\text {count }}^{2}=1,265<\chi_{\text {table }}^{2}=3,841$ at a significant level of $5 \%$ and degree of freedom 1 . This means that the sample has a homogeneous variance or comes from the same and homogeneous conditions.

\section{Average Initial Test Value of Similarity Test Results}

Based on the similarity test the average value of the initial ability is obtained $-t_{\text {table }}=$ $-1,99962<t_{\text {count }}=1,038<t_{\text {table }}=1,99962$ which means $\mathrm{H} 0$ is accepted. So, it can be concluded that there is no difference in the value of the initial ability of students class VII C (Experiment I) and class VII A (Experiment II) SMP Muhammadiyah 1 Sleman academic year 2015/2016. 


\section{Description of the Value of Mathematics Learning Outcomes Test}

Table 2. Summary of Descriptions of Values in Mathematics Learning Outcomes Test

\begin{tabular}{|l|c|c|}
\hline \multicolumn{1}{|c|}{ Variable } & Class Experiment I & $\begin{array}{c}\text { Class Experiment } \\
\text { II }\end{array}$ \\
\hline $\begin{array}{l}\text { The number of } \\
\text { students }\end{array}$ & 32 & 32 \\
\hline The highest score & 94,7 & 89,5 \\
\hline Lowest value & 42,1 & 36,8 \\
\hline Average $(\bar{x})$ & 75,00 & 67,92 \\
\hline $\begin{array}{l}\text { Standard } \\
\text { Deviation }(S)\end{array}$ & 13,74992045 & 13,1195849 \\
\hline Variance $\left(S^{2}\right)$ & 189,0603125 & 172,1093145 \\
\hline
\end{tabular}

\section{Normality Test Results Learning Outcomes Test Value}

This shows that the experimental class I mathematics learning outcomes value data are normally distributed because $\chi_{\text {count }}^{2}<\chi_{\text {table }}^{2}$ that is $2,9694<7,8147$ and class experiment II is normally distributed because $\chi_{\text {count }}^{2}<\chi_{\text {table }}^{2}$ that is $4,0737<7,8147$.

\section{Homogeneity Test Results Value Test of Mathematics Learning Outcomes}

Based on the homogeneity test that has been carried out in experimental class I and class II, it was obtained $\chi_{\text {count }}^{2}=0,17<\chi_{\text {table }}^{2}=3,8415$ so that $\chi_{\text {count }}^{2}<\chi_{\text {table }}^{2}$ there is a significant level of $5 \%$ and $\mathrm{df} 1$. This means that the sample has a homogeneous variance.

\section{Hypothesis testing}

1) First Hypothesis Test Results Value of Mathematics Learning Outcomes Test

$\mathrm{H}_{0} \quad: \quad \mu_{1}=\mu_{2}$

$\mathrm{H}_{1}: \mu_{1} \neq \mu_{2}$

Based on the results of the analysis carried out with a significant level of 5\% and 62 degrees of freedom, the values obtained $t_{\text {count }}=2,581>t_{\text {table }}=1,99962$, so that $H_{0}$ is rejected and $\mathrm{H}_{1}$ is accepted.

Thus, there are differences in mathematics learning outcomes between students who get learning with the Problem Posing type Post Solution Posing model and students who get learning with the TPSQ cooperative learning model on class VII students in the even semester of SMP Muhammadiyah 1 Sleman in academic year of 2015/2016.

2) Second Hypothesis Test Results Value of Mathematics Learning Outcomes

$\mathrm{H}_{0}: \mu_{1} \leq \mu_{2}$

$\mathrm{H}_{1}: \mu_{1}>\mu_{2}$

Based on the results of the analysis it appears that the value $t_{\text {count }}>t_{\text {table }}$ is at a significant level of 5\% and 62 degrees of freedom, so it can be concluded that $\mathrm{H}_{0}$ is rejected and $\mathrm{H}_{1}$ is accepted. Thus, mathematics learning of students who use the Problem Posing Post Solution Posing learning model is more effective than the TPSQ cooperative learning model for the mathematics learning outcomes of class VII Even Semester SMP Muhammadiyah 1 Sleman in 2015/2016 academic year.

This study aims to determine the effectiveness of two learning models, namely the Problem Posing learning model type Post Solution Posing and cooperative learning models TPSQ type class VII students in the even semester of SMP Muhammadiyah 1 Sleman 2015/2016 academic year. Based on these objectives, the research was conducted by involving two classes, namely class 1 experiment with 
32 students and experiment class 2 totaling 32 students. Experimental class 1, which is the class that gets treatment using the Problem Posing Post Solution Posing learning model, while the experimental class 2, which is the class that gets treatment using the TPSQ type cooperative learning model.

Based on the results of the analysis of the initial ability shows the condition of the sample before being given treatment has the same initial ability so that different treatments can be given, namely the experimental class 1 is given treatment using the Problem Posing learning model Post Solution Posing and experimental class 2 is treated using a model cooperative learning type TPSQ, then the two classes are given tests of mathematics learning outcomes.

Mathematics learning outcomes tests are given after the experimental class 1 and experimental 2 classes have finished. This aims to determine the learning outcomes of mathematics in both classes. Based on deskptive statistics on the value of mathematics learning outcomes, the average value obtained by the experimental class 1 is 75.003125 and the experimental class 2 is 65.7712125 . Hypothesis testing on mathematics learning outcomes is done to find out more effective learning models between the Post Solution Posing type Problem Posing learning model and the TPSQ type cooperative learning model.

Furthermore, because there are differences in learning outcomes between classes using the Problem Posing learning model Post Solution Posing type and the class that uses the TPSQ type cooperative learning model, the hypothesis is tested using the one-party t-test. From the results of the one-party hypothesis test $t_{\text {count }}=2.581$; and $t_{\text {table }}=1.67017$. because $t_{\text {count }}>t_{\text {table }}, H_{1}$ is accepted and $H_{0}$ is rejected. This means that the Problem Posing Posing Posing learning model is more effective than the TPSQ cooperative learning model for mathematics learning outcomes of class VII Muhammadiyah Middle School 1 Sleman even semester 2015/2016 academic year.

One of the factors that causes experimental class 1 to be more effective than experimental class 2 is in experimental class 1 learning using the Problem Posing learning model type Post Solution Posing, where students learn more independently to understand the subject matter, with self-learning students' memories will take longer because they make similar questions with what the teacher makes. In the Problem Posing learning model type Post Solution Posing, students are more active and motivated to solve problems given because each student is responsible for the results of group discussions and the problems they make. While learning in the experimental class 2 uses the cooperative learning model type TPSQ, where students are only responsible to the group, giving rise to a sense of dependence on other group members to do the assignments given by the teacher. This results in students being less likely to participate in their groups and eventually not understanding the material that has been taught.

\section{CONCLUSION}

Based on data analysis and discussion in this study can be concluded as follows:

1. There is a difference between the mathematics learning outcomes of students who learn using the Problem Posing Post Solution Posing learning model and the mathematics learning outcomes of students who learn using cooperative learning models TPSQ class VII type even semester 1 Muhammadiyah Junior High School 1 Sleman 2015/2016 academic year. This is indicated by the results of the first hypothesis test where with a significant level of 5\% and 62 degrees of freedom, the value of $t_{\text {count }}=2.581$ and $t_{\text {table }}=1.99962$ is obtained. Because $t_{\text {count }}>t_{\text {table }}, H_{1}$ is accepted and $\mathrm{HO}$ is rejected.

2. Mathematical learning of students learning using the Problem Posing Posing Posing learning model is more effective than the cooperative learning model TPSQ class VII students in the even semester of Muhammadiyah Middle School 1 Sleman 2015/2016 academic year. This is indicated by the results of the second hypothesis test where with a significant level of 5\% and 62 degrees of freedom, the value of $t_{\text {count }}=2.581$ and $t_{\text {table }}=1.67017$ is obtained. Because $t_{\text {count }}>t_{\text {table }}, H_{1}$ is accepted and $\mathrm{H}_{0}$ is rejected. 


\section{SUGGESTION}

1. For student

Students should always instill enthusiasm in themselves to be more active when participating in learning because student activities in learning greatly influence and support the achievement of learning goals.

2. For the teacher

For teachers, especially teachers in the field of mathematics studies in order to be able to choose the right and appropriate learning model between teaching material and the time of learning so that effective learning is realized for students. The teacher can use the Problem Solution Posing Posing learning model as an alternative or other variation in teaching that can make students more active during the learning process so that they can improve students' mathematics learning outcomes, and can create effective learning.

3. For schools

This research is expected to provide input to the school to always evaluate the teaching and learning process that occurs in the classroom so that the school can support the creation of new learning models that are more effective and in accordance with the conditions of students in order to improve the quality of education in schools.

4. For Further Researchers

Making this research a reference for future researchers in the preparation of scientific works, theses and other theses in the field of education.

5. For science

Providing information for further research by selecting other learning models that are thought to improve student learning outcomes.

\section{REFERENCES}

Arikunto, Suharsimi. 2013. Dasar-dasar Evaluasi Pendidikan. Jakarta: Bumi Aksara.

Lie, Anita. 2008. Cooperative Learning Mempraktikan Cooperative Learning di Ruang-Ruang Class. Jakarta: Grasindo.

Sudjana. 2005. Metoda Statistika. Bandung: PT Tarsito.

Sugiyono. 2015. Metode Penelitian Pendidikan. Bandung: Alfabeta.

Suparman. 2015. Metedologi Penelitian Pendidikan. Yogyakarta: MIPA UAD Press.

Thobroni, M. 2015. Belajar dan Pembelajaran. Jakarta: Ar-Ruuz Media. 